\title{
Açık Veri ve İş Zekâsı Teknolojisi: İstanbul Büyükşehir Belediyesi Dava Verileri Üzerine Bir Değerlendirme
}

\author{
Muhammet DAMAR $^{1 *(D)}$, Dilek KARAMAN ${ }^{2}$ \\ ${ }^{1}$ Lecturer Dr., Dokuz Eylül University, Information Technology Department, İzmir, Turkey \\ ${ }^{2}$ Asst. Prof. Dr., İzmir Demokrasi University, İzmir, Turkey
}

Geliş Tarihi/Received: 19.03.2021

Doi: 10.31200/makuubd.899741

Kabul Tarihi/Accepted: 15.04.2021

Araştırma Makalesi/Research Article

\section{ÖZET}

Son yıllarda dünyada açık veriye artan bir ilgi söz konusudur. Kurumların faaliyetlerini daha şeffaf ve verimli sürdürebilmeleri, hesap verilebilmeleri ve vatandaşın bilgilenmesi için, açık veri önemlidir. Kurumlar şeffaflık ilkesine bağlı kalarak faaliyet verilerini kamuya açabilmeli ve araştırmacıların bu veriden daha fazla faydalanmalarına imkân vermeleri gerekmektedir. Bu sayede kamu kurumlarındaki mali ve yönetimsel sorunlar veri merkezli ve bilimsel çerçevede kolayca sorgulanabilecektir. Bu çalışmada İstanbul Büyükşehir Belediyesi’nin açık veri olarak sunduğu dava verileri, iş zekâsı teknolojisi ile analizi gerçekleştirilmiştir. Çalışma kapsamında hukuk verilerinin seçilmesinin nedenleri hukuk verilerinin özünde bir sorundan kaynaklanması, bu verinin sorunun kaynağını tespit etmede nitelikli veri olarak kabul edilmesi, veri setinin açık olarak paylaşılmış olması ve Türkçe literatürde hukuk verilerini kullanan çalışmalara nadiren karşılaşılması olarak gösterilebilir. Açık verinin tercih edilmesindeki neden ise fikri mülkiyet kanunu ile konunun herkesce bağlacı olan lisans hakkı mevzuatından bağımsız olması ve araştırmacıların açık hükümet verilerinden özgür bir şekilde faydalanabilme imkânıdır. İstanbul Büyükşehir Belediyesi davaların \%72,16'sında davalı, \%10,84'ü borçlu taraf olarak bulunmaktadır. Dava dosya konuları değerlendirildiğinde, en yoğun açılan üç dava konusu sırasıyla; imar planı iptali (10.671), idari cezanın iptali (5.513), personel işleri hakkında davalar (1.628) şeklindedir. İmar planının iptali davasının yoğun olması, imar planı yapan birim faaliyetlerinin sorgulanmasını gerektiren önemli bir bulgudur. Geliştirilen uygulama, seçilen verinin konusu ve alanı, içerik bakımından niteliği ve kullanılan teknoloji gibi nedenlerden ötürü özgün bir çalışmadır.

Anahtar kelimeler: Açık Veri, Belediyeler, Açık Hukuk Verisi, İş Zekâsı, Veri Analizi.

* Sorumlu yazar/Corresponding author

E-mail/e-ileti: muhammet.damar@ deu.edu.tr 
Damar, M. \& Karaman, D.

\title{
Open Data and Business Intelligence Technology: An Evaluation on Istanbul Metropolitan Municipality Lawsuit Data
}

\begin{abstract}
There has been an increasing interest in open data around the world in recent years. Open data is important for institutions to carry out their activities more transparently and efficiently, to be accountable and to inform the citizens. Institutions should adhere to the principle of transparency and be able to make their activity data public and allow researchers to benefit more from this data. In this way, financial and administrative problems in public institutions can be easily questioned in a data-centered and scientific framework. In this study, the case data presented by Istanbul Metropolitan Municipality as open data was analyzed with business intelligence technology. The reasons for the selection of court data within the scope of the study can be shown as the fact that court data originate from an inherent problem. This data is accepted as qualified data in determining the source of the problem, the data set is openly shared, and studies that use court data are rarely encountered in the Turkish literature. The reason for choosing open data is that it is independent of the intellectual property law and licensing rights legislation that are bound by everyone, and researchers can freely benefit from open government data. Istanbul Metropolitan Municipality is the defendant in $72,16 \%$ of the cases. It is the debtor party in $10,84 \%$ of the cases. When the lawsuit file issues are evaluated, the three most intense lawsuit subjects are respectively; zoning plan cancellation (10.671), cancellation of administrative penalty (5.513), lawsuits about personnel affairs (1.628). The fact that the case of annulment of the zoning plan is intense is an important finding that requires questioning the activities of the unit that makes the development plan. The application developed is an original work due to reasons such as the subject and area of the selected data, its content in terms of content and the technology used.
\end{abstract}

Keywords: Open Data, Municipalities, Open Juristic Data, Business Intelligence, Data Analysis.

\section{GÍRİŞ}

Son y1llarda dünyada açık veriye artan bir ilgi söz konusudur. İçinde bulunduğumuz hızla dijitalleşen dünyada, kamu kurumları ve özel işletmeler ürettikleri veri ve bilgilerin ücretsiz ve yeniden kullanımını sağlamak amacıyla ülkelerinin yasa ve yönetmeliklerine bağlı kalarak veriyi kamuya açmaktadır. Telif hakkı, patent veya benzer koruma yöntemlerine, hukuk ve mevzuat kısıtlamalarına gerek duyulmaksızın veriler, kamuya açık şekilde paylaşılmaktadır. 
$\mathrm{Bu}$ şekilde paylaşılan veriler açık veri olarak adlandırılmaktadır. $\mathrm{Bu}$ veriler, yeni bilgiler edinmek amacıyla pek çok paydaş tarafından bir kaynak olarak görülmektedir. Ayrıca açık veri, vatandaşlar, işletmeler ve hükümetler için yeni hizmet ve yeni ürün oluşturmak veya sağlamak için kullanılmaktadır (Golub \& Lund, 2021).

Son zamanlarda açık veri, hızlı artan açıklık talebi bağlamında daha fazla önem kazanmaktadır. Bu doğrultuda ihtiyacın karşılanması için devlet politikası halini almaktadır. Örneğin, Amerika Birleşik Devletleri (Özellikle 44. ABD Başkanı Barack Obama Dönemi) (ObamaWhiteHouse, 2021) ve Avrupa Komisyonu (EuropaData, 2021) bu yöndeki gelişmeleri desteklemiştir. Hatta bu durum kamu ve özel kuruluşları, veri paylaşımı konusunda baskı altına sokmaktadır. Dünyanın her yerinde gerek kamu gerekse özel kuruluşlar verilerini yayınlamaya başlamışlardır (Zuiderwijk vd., 2012, s.156). Türkiye'de açık bilim ve açık veri üzerinde pek çok kamu kurumu ve özel işletme çalışma gerçekleştirmektedir. Bu çalışmalara örnek olarak; Açık Bilim Türkiye (Açık Bilim Türkiye, 2021), Açık Veri İzmir (İzmir Açık Veri, 2021), İstanbul Büyükşehir Belediyesi (İBB) Açık Veri Platformu (İBB Açık Veri, 2021), Blockchain Türkiye Platformu (Blockchain Türkiye, 2021) gibi çalışmalar belli başlı açık veri kaynakları olarak gösterilebilir. Türkiye Bilimsel ve Teknolojik Araştırma Kurumu (TÜBİTAK) da bu yönde Açık Bilim Politikası (TÜBİTAK Açık Bilim, 2021) yayınlamıştır.

Kazaz (2020, s.1), dünya üzerinde pek çok yerel yönetim ve kamu dairesi verilerini açık bir şekilde halkın kullanımına açtığını ifade etmiştir. Vatandaşlarına bu şekilde kolay erişim hakkı sunan devletlerin, topluma karşı şeffaflık ve hesap verilebilirlik ilkelerini yerine getirdiğini belirtmiştir. Kamu kurumları verilerinin şeffaflığı, vatandaşlara hükümetin nasıl çalıştı̆̆ına dair bir fikir vermektedir. Devlet verilerine erişim, kamu yararına bir konudur. Çünkü eylemleri halkı birçok yönden etkiler. İnternetin yaygınlaşması ve bilgi teknolojilerinin hızlı gelişimi ile açık verinin paylaşımı ve erişimi kolaylaşmıştır. Öte yandan, kişisel veriler bazen devlet verilerinin bir parçasıdır ve mahremiyetlerini korumak vatandaşların yararınadır. $\mathrm{Bu}$ zıt beklentiler, özellikle önemli miktarda kişisel verinin bulunduğu yargıda bu tür verilerin yayınlanmasını zorlaştırmaktadır (Marković vd., 2016). Elbette açık verinin paylaşılmasında Kişisel Verilerin Kullanımına Dair Kanunun (KVKK, 2016) gereksinimleri dikkate alınıp bu kanuna bağlı kalınarak kurumların verilerini paylaşması gerekmektedir.

Araştırmacılar, kamuya açılan açık veri sayesinde ilgili alandaki kurumların faaliyetleri üzerinde değerlendirmeler yapabilmektedir. Sunulan veri ve verinin niteliği dikkate alınarak oluşturulan sorular ve araştırmacının konuya ilgisi, verilerden edinilecek fayda için önem 
taşımaktadır. Veri değerini ve kıymetini araştırmacı tarafından ortaya konulan sorulara verdiği cevaplar sonucunda bulabilmektedir. Açık veri için araştırmacı, farklı bir ülkede çalışan bir akademisyen olabileceği gibi, aynı kurumda farklı birimde çalışan bir memur da olabilir. Bu bağlamda üzerine çalışılan veri sayesinde yönetimsel faaliyetler için daha iyi karar verebilmek, alan hakkında daha iyi değerlendirme yapabilmek önemli bir unsur olarak karşımıza çıkmaktadır. Karar verme ve veri sözcükleri iç içe geçtiğinden dolayı güncel teknolojilerin kullanımı önemli hale gelmiştir. İş zekâsı teknolojisi bu konuda uygulanabilecek çözümlerden bir tanesidir. İş zekâsı, işletmelerin geçmişten günümüze ürettikleri büyük ölçekli ham verilerini yönetmek, anlamlı bilgilere dönüştürmek için kullandıkları süreçler ve teknolojilerdir. $\mathrm{Bu}$ anlamlı bilgileri kullanarak, işletmeler süreçlerindeki eğilimleri görebilmekte ve gelecek için tahminlerde bulunabilmektedirler. Kurum, tahmin ettiği sonuçla, kararın etkin bir şekilde alınmasına olanak sağlayacak yararlı bir dizi strateji oluşturabilmektedir.

Karar verme teknikleri genellikle, orta ve üst düzey yöneticilere yönelik, karar destek sistemleri ve uzman sistemlerin içerisine bir bileşen olarak girmekte, bilgi sistemi içerisinde bütünleşik olarak kullanılabilmektedir. İş zekâsı, operasyonel seviyeden yönetici seviyesine kadar her kademede çalışanlara yönelik performans çıktıları sunulabilmektedir. Ayrıca günlük veya daha uzun dönemleri kapsayacak şekilde performans yönetim mekanizmas1 sağlamaktadır. Diğer karar destek sistemleriyle de bütünleşik olarak çalışabilen iş zekâsı, veri yönetimi, veri analizi, verinin görselleştirilmesi, veri madenciliği gibi yöntemlerin kullanımı için araçları içinde barındırmaktadır.

Açık veri ve iş zekâsı teknolojilerini kavramsal olarak değerlendirildiğimizde, birbirine organik bağı olan ve verinin etkin değerlendirilmesi, verinin üzerinden yöneticiye veya araştırmacıya karar veya varsayım açısından destek olması adına önemli iki kilit teknoloji ve yaklaşım olduğu ifade edilebilir. Çalışma bu yönüyle İBB'nin açık veri portalında (Bakınız, İBB Açık Veri, 2021) yer alan hukuk verilerini, iş zekâsı teknolojisi kullanarak bir değerlendirme ortaya koymaktadır. Gerçekleştirilen çalışmanın Türkiye'deki açık veri konusunun içinde bulunduğu durumu ortaya koyması ve değerlendirmesi, bunu iş zekâsı gibi çok güncel bir teknoloji ile bir kamu kurumunun hukuki faaliyetlerini içinde barındıran bir açık veri ile ortaya koymasının farklı ve değerli görülmektedir. Yapılan literatür araştırmasında iş zekası ve açık veri konularında literatürde önemli bir boşluğun olduğu görülmüştür. Ayrıca açık veri ve bu verinin kamu kurumları tarafindan paylaşılmasının hukuka ne kadar uygun olduğu konusuna makalenin bütününde cevap aranmaktadır. Tüm bunların yanında yaklaşık yirmi milyon nüfusa sahip ve dünyanın en büyük metropollerinden birisi olan İstanbul'un büyükşehir 
belediyesine ait dava verilerinin niteliği ve verilerin analizi sonucunda yapılan değerlendirme de alanda çalışanlara farklı bir bakış açısı sunacaktır. Çalışma, geliştirilen uygulama için seçilen veri kaynağı, verinin niteliği ve kullanılan teknoloji açısından alan için önem ve değer taşımaktadır.

\section{AÇIK VERİ, AÇIK BİLIM VE AÇIK HÜKÜMET VERILERİ}

Açık veri terimi, çoğu paydaş tarafından hükümet, sağlık, bilim ve tarım gibi pek çok alanda sıklıkla kullanılmaktadır. Bu alanların her bir paydaşı, farklı biçimlerde yayınlanan açık verilere erişebilir. Açık veri teriminin genel olarak kabul gören tanımı, bir web sayfası aracılığ ile internet üzerinden kolayca ve serbestçe erişilebilien, okunabilir biçimde yayınlanan, paylaşılabilen ve herhangi bir kullanıcı veya paydaş için yeniden kullanımına izin verilmiş olan veri şeklindedir (Carolan vd., 2015). Açık veri platformları veya portalları, verilere dayalı yenilikçi yazılım uygulamaları ve hizmetleri geliştirmek ve sunmak amacıyla bireysel yazılım geliştiricileri, araştırmacılar veya konuyla ilgili pek çok kişi veya kurum tarafından kullanılabilir (Kostovski vd., 2012). Bu durum açık verinin felsefesi ile doğrudan örtüşmektedir. Halonen (2017) açık veriyi, herkes tarafından serbestçe tekrar tekrar kullanılabilen ve dağıtılabilen veriler olarak özetlemiştir. Açık veri geliştirme modeline göre açık veri yönetim süreci beş adımdan oluşur ve bu adımlar; açık verinin kontrol edeilmesi, erişimi, kullanımı ve yeniden kullanılması; yeni açık veri kümesi oluşturma; açık verileri değerlendirme ve seçme; açık verileri dönüştürme; açık verileri kontrol etme veya yayınlama, şeklindedir (Sowe \& Zettsu, 2015).

Açık veri kolayca ve uygun formatta her zaman erişilebilir, kullanılabilir ve paylaşılabilirdir. Bu nedenle diğer veri türlerinden farklı olarak, tüm paydaşlar için ilgili alana etkin katkı sağlama açısından büyük öneme sahiptir. Birbiriyle ilişkili veriler arasında bağlantılar oluşturmak, paydaşların ilgili alanlarda çok daha karmaşık verilere erişmesini sağlar. Bu kadar değerli verilere erişim, paydaşlar tarafından ilgili alana değerli katkılar sağlamada olumlu bir etkisi vardır (Bizer vd., 2009).

Son on yılda dünyada açık veriye artan bir ilgi söz konusudur. Dünyada başlayan açık veri girişimi, European Data Portal verisine göre Avrupa'da 35 ülkede, Open Data Baromater'ın yayınladığı rapora göre ise dünyada toplam 115 ülkede mevcuttur. Dünya genelinde açık veri çalışmaları hız kazanmış ve araştırmacılar, vatandaşlar ve özel şirketlerin özgürce indirilebilen ve erişilebilen açık veriye ulaşması sağlanmıştır (Kazaz, 2020, s.9). Bu araştırmada kullanılan 
veri, bahsedilen açık veri kaynaklarından bir tanesi olan İstanbul Büyükşehir Belediyesi (İBB) Açık Veri Platformundan elde edilen İBB'ye ait dava verileridir.

Open Definition (2021), bilgi ile ilgili olarak “açık” veya “açıklık” sözcügünün anlamını netleştirmektedir. Açıklık, herkesin katılabileceği, sağlam, müşterekleri teşvik eden ve birlikte çalışabilen veri olarak ifade edilmektedir. Bilgi eğer erişim, kullanma, değiştirme ve paylaşma özgürlüğüne sahipse açıktır. Ayrıca Rouder (2016), "açık bilimin kritik bir parçası açık veridir” şeklinde ifade etmiş ve ham verileri talep üzerine herkesin kullanımına sunma eylemi olarak belirtmiştir. Son zamanlarda, araştırmacıların verilerini açık hale getirmeleri bilimsel faaliyetlerdeki araştırma maliyetlerini düşürücü bir etken olarak da karşımıza çıkmaktadır.

Açık bilim, bilgi yaratma ve yaymanın geleceği hakkında çok sayıda varsayımı kapsayan şemsiye bir terimdir. Açık bilim, bilim dünyasının özellikle son zamanlarda yoğun kullandığı moda sözcüklerinden biridir. Dahası, bilimsel bilginin yaratılması ve yayılmasının geleceğine ilişkin her türlü değişikliği açıkça kapsayan, canlı ve gelişen bir yapıdır. Aslında, bu terim alan araştırmacıları ve diğer paydaşlar üzerinde oldukça farklı anlamlar uyandırmaktadır. Kamu tarafından finanse edilen bilgiye erişim hakkı (Yayınlara açı erişim) veya araştırma ile toplum arasında daha iyi bir köprü kurma talebi (Vatandaş bilimi), işbirliği için ücretsiz olarak kullanılabilen araçların geliştirilmesi (Bilim adamları için sosyal medya platformları) bu kavramlara örnek gösterilebilir. Bu bakış açısından, açıklık hemen hemen her şeye atıfta bulunabilir: Bilgi yaratma süreci, sonucu, araştıran kişinin kendisi veya araştırma ile toplumun geri kalanı arasındaki ilişki (Fecher \& Friesike, 2014, ss.17-18).

Kamu kurumlarının açık veriden elde edilen pek çok faydanın yanında, açık verinin sağladığı ekonomik katkı üzerinde durmak gerekmektedir. Avrupa Veri Portalı tarafından açık verilerin ekonomik değeri araştırılmış ve elde edilen veride 2019 yılı için açık verinin oluşturduğu pazarın büyüklüğünün 184 milyar Avro olduğu belirtilmiştir. Bu pazarın 2025 yılı içinde 199,51 milyar Avro ile 334,21 milyar Avro arasında olacağı tahmin edilmektedir (European Data Portal, 2021).

Açık veriler, özünde çok çeşitli farklı unsurların bir birleşimidir ve bu nedenle, farklı insan grupları için farklı hedefler ve faydalarla ilişkilendirilir. Tek bir hedef modeli yoktur, hedeflerin ve potansiyel faydaların birlikte bir derlemesini oluşturan birbiriyle ilişkili çeşitli uygulama alanları vardır (Halonen, 2017). Dahası, örneğin Rufus Pollock’un ileri sürdüğü gibi, açık veri, kendi başına bir amaç değil, esasen bir amaca yönelik bir araçtır (Pollack, 2011). 
Dolayısıyla açık verinin hedefleri, ekonomi, demokrasi veya kamu hizmetleri alanında belirlenen hedeflerle ilişkilidir.

Daha şeffaf ve verimli bir hükümet yapılanması için, oluşturabileceği potansiyel etki değerlendirildiğinde açık veriden daha fazla faydalanılması gerektiği ifade edilebilir. Toplumsal sorunlar, bunların bilimsel çerçevede değerlendirilmesi, artan ticari faaliyetlerin ve harcamaların yönetimi, şeffaflık ilkesiyle sorgulanması daha kolay gerçekleşebilir. Welle Donker ve van Loenen (2017, s.284) açık veri konusunun şu anda sıcak bir konu olduğunu ifade etmiştir. Ülkeler ve kuruluşlardaki açık verilerin durumunu tanımlamak ve izlemek için pek çok açık veri değerlendirme çerçevesi geliştirildiğini ifade etmişler ve bu değerlendirme çerçevelerindeki yüksek puanlara rağmen, açık devlet verilerinin (Open Government Data) hala gerek verinin niteliği gerekse kaynakların çokluğu hususunda beklentileri karşılayamadığını ifade etmişlerdir.

Açık Hükümet Verileri web sitesinden elde edilen veriler 1şığında (Opengovdata, 2021), açık hükümet verileri değerlendirildiğinde, hükümet verileri, aşağıdaki ilkelere uygun bir şekilde kamuya açıklanırsa açık kabul edilmektedir:

- Tam ve eksiksizlik: Tüm veriler herkese açık olarak kullanıma sunulmuştur. Herkese açık veriler, geçerli gizlilik, güvenlik veya ayrıcalık sınırlamalarına tabi olmayan verilerdir.

- Birincil öncelikli: Veriler, toplu veya değiştirilmiş formlarda değil, mümkün olan en yüksek ayrıntı düzeyinde toplandığı gibidir.

- Zamanında: Verilerin değerini korumak için veriler gerektiği kadar hızlı bir şekilde sunulur.

- Erişilebilir: Veriler, çok çeşitli amaçlar için en geniş kullanıcı yelpazesine sunulur.

- İşlemeye ve analiz yapmaya uygun: Veriler, otomatik işlemeye izin verecek şekilde makul şekilde yapılandırılmıştır.

- Adil: Veriler, kayıt zorunluluğu olmaksızın herkes tarafından kullanılabilir.

- Telif ile korunmaz: Veriler, üzerinde hiçbir kuruluşun münhasır kontrole sahip olmadığı bir formatta mevcuttur. 


\section{Damar, M. \& Karaman, D.}

- Lisans gerekmez: Veriler herhangi bir telif hakk1, patent, ticari marka veya ticari sır yönetmeliğine tabi değildir. Makul gizlilik, güvenlik ve ayrıcalık kısıtlamalarına izin verilebilir. Uygunluk gözden geçirilebilir olmalıdır.

Açık hükümet verilerinin tercih edilmesi, fikri mülkiyet kanunu ile konunun bizleri bağladığı lisans hakkı mevzuatından bağımsız olması ve araştırmacıların açık hükümet verilerinden bağımsız bir şekilde faydalanabilmesi gerçeğidir. Açık hükümet verileri için yine aynı sitede sözü edilen "kamuya-halka açıklık", "veri” ve "incelenebilir” sözcüklerini açmakta fayda olacaktır. Bu tanımlar veya kavramlar şu şekilde açılabilir (Opengovdata, 2021):

- Kamuya-halka açı: Açık Hükümet Verileri ilkeleri, hangi verilerin halka açık olacağını hangisinin olmayacağını ele almaz. Gizlilik, güvenlik ve diğer kaygılar, veri setlerinin halka açık olup olmama durumunu özetle paylaşılmasını yasal olarak (ve haklı olarak) engelleyebilir. Aksine, bu ilkeler, kamuya açık verilerin "açık” olarak kabul edilmesi için karşılaması gereken koşulları belirtmektedir.

- Veri: Elektronik olarak saklanan bilgiler veya kayıtlar olarak ifade edilmektedir. Örnekler arasında belgeler, sözleşmelerin veritabanları, duruşmaların tutanakları ve olayların sesli-görsel kayıtları yer alabilmektedir. Fiziksel eserler gibi elektronik olmayan bilgi kaynakları, Açık Hükümet Verileri ilkelerine tabi olmasa da, bu tür kaynakların mümkün olduğu ölçüde elektronik olarak kullanılabilir hale getirilmesi her zaman teşvik edilmektedir.

- İncelenebilir: Verileri kullanmaya çalışan kişilere yanıt vermek için bir irtibat kişisi atanmalıdır. İlkelerin ihlali ile ilgili şikâyetlere yanıt vermek için bir irtibat kişisi atanmalıdır. Bir idare veya adli mahkeme, ajansın bu ilkeleri uygun şekilde uygulayıp uygulamadığını inceleme yetkisine sahip olmalıdır.

Yukarıdaki tanımlar göz önünde bulundurulduğunda Türkiye'de açık verinin kullanımı ve ortaya çıkacak hukuki problemler sonrasında yapalabilecekler konusunda yeterli olmadığımız, bu alanda daha fazla çalışma ve araştırmanın gerçekleştirilmesi gerektiği ifade edilebilir. Konunun tüm kamu kurumlarını bağlayacak bir bütünsellik ve kapsamda, tüm kanunlar ile ilişkili, çatı bir yapıya kavuşturulması gerektiği ifade edilebilir. Bu sayede açık verinin kullanımından doğabilecek sakıncalar hususunda gerek veri sahibi kurum ve kuruluşların zarar görmesi engellenecek, gerekse bu veriden faydalanacak araştırmacıların korunması, araştırma bulgularının ilgili kurumların etkinliğini artırması, alana katkı sunması sağlanabilecektir. 


\section{3. İȘ ZEKÂSI}

İş zekâsı, şirketlerdeki bilgisayar biliminin rolünü, verileri pasif olarak depolamaya yönelik bir teknolojiden, önemli işletme faktörlerini zamanında tespit etmek ve stratejik kararların alınmasındaki zorlukları ortadan kaldırmak için kullanılabilecek bir disiplindir. İş zekâsı, şirketlerdeki bilgisayar biliminin rolünü, verileri pasif olarak depolamaya yönelik bir teknolojiden, önemli işletme faktörlerini zamanında tespit etmek ve stratejik karar sorunlarını etkin bir şekilde çözmek için bir disiplin haline getirmiştir. Bununla birlikte, mevcut değişken ve öngörülemeyen piyasa senaryolarında, karar vericilerin ihtiyaçlarına da hızla cevap verebilmekte, karar vericiler için iş zekâsı sistemleri bir çözüm olarak ortaya koyabilmektedir.

İş zekâsı, karar vermeyi geliştirmek için kullanılan bir teknoloji ve uygulama koleksiyonudur (Mudzana \& Maharaj, 2015, s.2). İş zekâsı, iş dünyasında bilinçli kararları destekleyen teknoloji ve araçlar için kavramsal bir şemsiye olarak tanımlanmaktadır (Wowczko, 2013, s.1107). Oluşturulan bilgi ve beceriler, organizasyonlara değer ve rekabet avantajı yaratma ve sürdürme potansiyeli sağlamaktadır (Mitchell \& Boyle, 2010, s.67). İş zekâsı, organizasyonlarda çeşitli amaçlarla kullanılabilmekte, kullanıcı sayısı ve kullanım alanları karar desteği ihtiyaçları doğrultusunda farklılık gösterebilmektedir. Getirdiği yeniliklere paralel olarak, yaygınlaşma hızı da artan bir eğilim göstermektedir (Ateş, 2008, s.45). İ̧̧ zekâsının, kullanıcılarına verilerini birleştirme, analiz ve raporlama işlevlerini sunarak kuruluşun verilerinin en iyi şekilde kullanılmasına olanak tanıyan bir bilgi ve iletişim teknolojisi aracı olduğunu da tanımlar içerisinde vurgulanan bir ifadedir (Hartley \& Seymour, 2010, s.116).

İş zekâsı, operasyonel düzeyden strateji düzeyine kadar çok çeşitli işletme kararlarını desteklemek için kullanılabilmektedir. Temel işletme kararları, fiyatlandırma veya malzeme planlama gibi günlük operasyonları içermektedir. Stratejik iş kararları, bir işletme olarak kalmaya devam edip etmeme (öncelikler), yüksek düzeyde hedefler ve yönergeler gibi uzun vadeli etki faaliyetlerini içermektedir. İşletme, hem harici (piyasadan, sosyal medyadan elde edilen veriler) hem de dâhili (finans ve operasyon verileri gibi) bilgilere ihtiyaç duymaktadır. $\mathrm{Bu}$ veriler birleştirildiğinde, gerçekte herhangi bir tekil veri kümesinin sağlayamayacağı düzeyde zekâ ortaya koyan eksiksiz bir resim oluşturulabilmektedir (Pham vd., 2016, s.569).

İş zekâsı projelerinin başarılı bir şekilde sonuçlandırabilmek için bazı zorlukların üstesinden gelmek gerekebilir. Projenin başarılı olabilmesi için, birim bazlı gerçekleştirebilecek 


\section{Damar, M. \& Karaman, D.}

proje veya projenin parçaları için odaklanılmış, ihtiyaca dönük çalışmaların gerkesinimi; yetenekli ekip üyelerine olan gereksinim; kapsamlı ihtiyaçlaırn iyi bir şekilde özümsendiği proje planlaması; verilerin standardizasyonun ve kalitesinin sağlanması, gerek görülen iş zekâsı araçlarının ihtiyaç ve proje kapsamında kullanılması gerekmektedir. Seddon (1997, ss.242246), sistem kalitesi, başarılı bir iş zekâsı konumlandırılması için önemli bir faktör olduğu ifade edilmiştir. Geçmiş araştırmacılar, sistem kalitesini, sistemde hata olup olmadığı, kullanıcı ara yüzünün tutarlılığı, kullanım kolaylığı, dokümantasyon kalitesi ve program kodunun kalitesi ve bakımı olarak tanımlamışlardır.

İş zekâsı, işletmelerin geçmiş ve güncel verilerdeki büyük ölçekli ham verileri yönetmek ve bunları anlamlı bilgilere dönüştürmek için kullandıkları süreçleri ve teknolojileri kapsar. $\mathrm{Bu}$ anlamlı bilginin bir sonucu olarak, işletmeler veya kurumlar operasyonlardaki eğilimleri görebilir ve gelecek için tahminlerde bulunabilir. Kurum, tahmin ettiği sonuçla kararın etkili bir şekilde alınmasını sağlayacak bir dizi faydalı strateji oluşturabilir (Foley \& Guillemette, 2010; Elena, 2011; Pham, 2016). İş zekâs1, sisteminin temel süreci verilerin bilgiye, kararlara ve nihayetinde eyleme dönüştürülmesine dayanmakla birlikte genel bir mimariye de sahip olduğu söylenebilir (Sharda vd., 2015, s.43; Eckerson, 2003, s.32). Kamu kurumları ve özel işletmeler faaliyetlerini sürdürmek için karar desteğine ihtiyaç duyan dinamik kuruluşlar veya kurumlardır. Bu nedenle iş zekâsı, gerekli desteği karşılamak için ilgili bir dizi araç ve teknoloji sağlamaktadır.

İş zekâsı hacim ve önem bakımından büyümeye devam ettikçe, iş zekâsının organizasyonlarda başarılı bir şekilde konuşlandırılması ihtiyacı artmaktadır (Heinrichs \& Lim, 2003, ss.103-104). Abukari ve Job (2003, s.15), iş zekâsını başarılı bir şekilde uygulamak için altı aşamalı bir yaklaşım önermektedir. Bu aşamalar şu şekildedir: (1) iş stratejileri ve hedefleriyle bağlantılı iş zekâları ihtiyaçlarını tanımlama, (2) çoklu veri kaynaklarını tanımlama, (3) konu odaklı bir veritabanı oluşturmak için verileri ayıklama, dönüştürme ve yükleme, (4) kuruluşun seçmesine yardımcı veritabanını görüntülemek ve analiz etmek için bir raporlama motoru, (5) standart raporlar oluşturmak ve kurumsal performansın temel itici güçleri hakkında içgörüler elde etmek için geçici analiz ve veri madenciliği yapmak ve (6) doğru kararı sağlamak için işletme çapında bir dağıtım planlamak.

İş zekâsı teknolojisini yukarıda ortaya konulan unsurlar dikkate alınarak değerlendirelim. Bu teknoloji için veri, temel kaynak veya başka bir deyişle bir nevi hammadde niteliği taşımaktadır. Bilgi hiyerarşisi içinde yer alan; veri, enformasyon, bilgi ve bilgelik 
konuları iş zekâsı teknolojisi ile doğrudan örtüşmektedir. Bilginin yönetsel faaliyetlerde, karar vericilerin belleğinde hayat bulması için iş zekâsı gibi teknolojilere ihtiyaç vardır. Açık veri, bilginin dönüşümü ve oluşturduğu etki bakımından kritik değere sahip önemli bir veri kaynağı veya yaklaşımdır.

\section{METODOLOJİ}

İş zekâsı ve veri madenciliği kapsamında yapılan bilimsel araştırmalar sonucunda ortaya çıkan yayınlar ile birlikte toplanan veri değer taşımaktadır. İşletmeler bünyesinde büyük ölçekli veriler toplansa da bu verilerin taşıdığı gizlilik ve özellikler nedeniyle genellikle bilimsel çalışmalarda sıklıkla yer bulamamaktadır. Özellikle metodolojik çalışmaların geliştirilmesi, çalışmalar arasında kıyaslamalar yapılabilmesi, eğitsel amaçlı kullanılabilmesi adına, verilerin paylaşılması beklenmektedir. Bu amaçla geliştirilmiş veri paylaşım platformları bulunmaktadır ve gönüllülük esasıyla, çalışmalarda kullanılan veriler bu platforma bağışlanabilmektedir. $\mathrm{Bu}$ tür sistemler açı veri sistemleri veya portalları olarak adlandırılmaktadır. Bağışlanan verilerin kullanıldığı çalışmalara da bu sayede ulaşmak mümkün olmaktadır. Çalışmada, İBB Dava Bilgileri başlıklı veri setinden yararlanılmış (İBB Açık Veri, 2021) ve iş zekâsı araçları yardımı ile veri pek çok boyutta analiz edilmiştir.

Çalışmada hukuk veri setinin seçilme nedeni, Türkçe literatürde hukuk verilerine çok nadir karşılaşılması ve veri setinin herkese açık olmasıdır. İstanbul sadece Türkiye'nin değil dünyanın en önemli şehirlerinden birisi olması itibariyle, bu kenti ilgilendiren dava verilerinin analizinin önemli görülmesi ve ilginç olacağı düşüncesi de bir başka nedendir. İBB Hukuk müşavirliği tarafından İBB'nin yıllar içinde taraf olduğu davalar 13 Şubat 2020 güncelleme tarihiyle kamuya açılmıştır. Aşağıda Şekil 1 üzerinde verinin excel görünümü, veri künye bilgileri, Tablo 1 üzerinde dava bilgileri veri sözlüğü bilgileri sunulmaktadır. Verinin en son güncellenme ve oluşturulma tarihi, 13 Şubat, 2020, Excel (Xlsx) formatında, İstanbul Büyükşehir Belediyesi Açık Veri Lisansı ile dağıtılmakta, veri büyüklüğü 2.7 MegaByte, veri seti id'si "F6695c85-7798-49e5-A041-0e9d3616a75a", resource id "C184a1a9-05ed-4ea6Afce-09bb5b86b78e”, değişim id'si “3da25038-527f-488c-B1b0-9cf04913b649” şeklindedir. Elde edilen dava kayıt sayıs1 64.292'dir. Bu verilere https://data.ibb.gov.tr/dataset/ibb-davabilgileri adresi üzerinden ilgili tanım numaralarını (ID: c184a1a9-05ed-4ea6-afce09bb5b86b78e) kullanılarak ulaşılabilir. 


\section{VERİ METADATA}

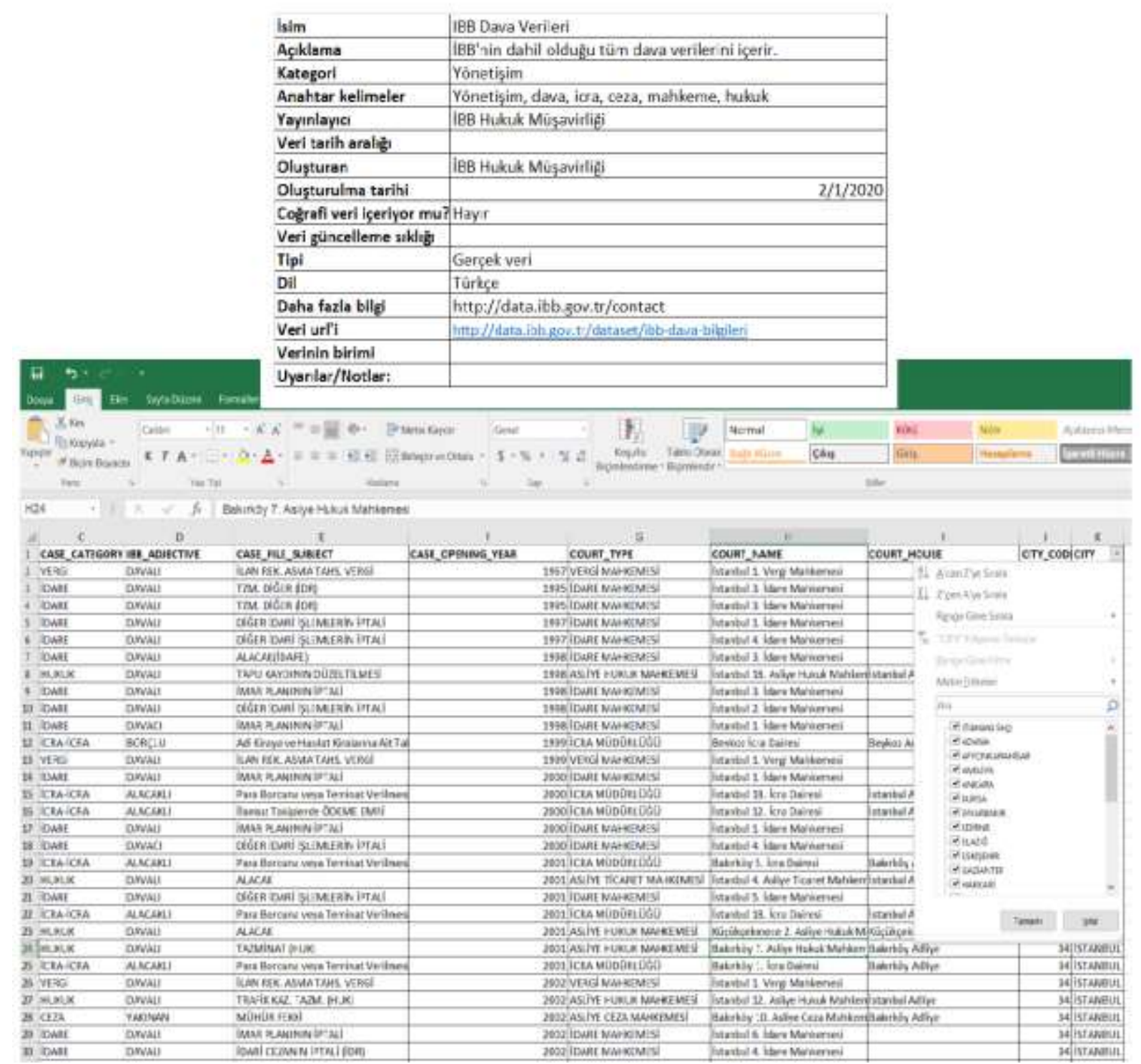

Şekil 1. Verinin excel görünümü ve verinin künye bilgisi

Verilen bilgiler, kurgulanan bir problem üzerinden Power BI (Power BI, 2020) ortamında gerçekleştirilen analizler ile örneklendirilmektedir. Power BI, Microsoft firması tarafindan sunulan, hem veri üzerinde önişlemeler yapabilmek ve görsel araçlar geliştirmek, hem de ileri analizler gerçekleştirmek üzere pek çok araç sağlayan bir iş zekâsı ortamıdır. Çeşitli yetkilendirmelerle, oluşturulan uygulamaların organizasyon bünyesinde gerçek zamanlı ve paylaşımlı kullanılmasını sağlayan modüllere sahiptir. Uygulama örneği için bu ortamın seçilmesinin temel nedeni, örnek uygulamaların MS-Excel hesap tabloları üzerinden sunulması ve bu anlamda kolay, etkin ve tam bir uyum sağlanabilmesidir. 
Tablo 1. İBB dava verileri veri sözlüğü

\begin{tabular}{|l|l|l|}
\hline Kolon & Tip & Açıklama \\
\hline STATUS & Text & Dava durum bilgisini içerir. \\
\hline CASE_TYPE & Text & Dava tipini içerir, dava, icra gibi. \\
\hline CASE_CATEGORY & Text & Dava kategorisini içerir. \\
\hline IBB_ADJECTIVE & Text & İBB'nin davadaki rolünü içerir. \\
\hline CASE_FILE_SUBJECT & Text & Dava dosyası konu bilgilerini içerir. \\
\hline CASE_OPENING_YEAR & Numeric & Dava açılma yını bilgisini içerir. \\
\hline COURT_TYPE & Text & Mahkeme türü bilgisini içerir. \\
\hline COURT_NAME & Text & Mahkeme adı bilgisini içerir. \\
\hline COURT_HOUSE & Text & Mahkeme yeri bilgisini içerir. \\
\hline CITY_CODE & Numeric & Şehir kodu bilgisini içerir. \\
\hline CITY & Text & Şehir bilgisini içerir. \\
\hline
\end{tabular}

Çalışmada yürütülen analizlerde veri seti kaynaklı bazı kısıtlar ile karşılaşılmıştır. Açık veri için kullandığımız veri için yıllara göre dağılımında bazı eksiklikler görülmüştür. Örneğin dava verileri için 2028, 2027, 2026, 2025, 2024, 2023 y1lına ait verilerin bulunması sunulan açık verinin niteliği konusunda soru işaretleri uyandırmaktadır. Ayrıca geçmişe dönük dava verilerinin azlığı da arşivleme veya geçmişteki bilgilerin dijitalize edilmesi ile ilgili problemleri işaret etmektedir. Tablonun bazı kolonlarında sunulan veride "null" yani girilmeyen değerlerinin bulunması da çalışmanın bir başka kısıtıdır. Açık veriden araştırmacıların daha iyi faydalanabilmesi için verinin mümkün olduğu kadar tutarlı, detaylı ve doğru sıfatlarını taşıması gerektiği ifade edilebilir.

\section{BULGULAR VE TARTIŞMA}

Açık veri bilimine ilgi duyan araştırmacılar ve diğer paydaşlar tarafından, kamu ve özel kuruluşlar tarafından sağlanan verilerin daha fazla açılması için artan bir talep söz konusudur. Sadece verilerin araştırma niteliği, bilimsel katkı konusunda değil toplumsal, ekonomik ve pek çok diğer başlıkta da potansiyel etkiye sahip olduğu ortadadır. Bununla birlikte, amaçlanan olumlu etkilerin farkına varmak ve açık veriyi geniş ölçekte kullanarak değer yaratmak çok önemlidir. Verilerin açılması ve kullanılması, hem sosyal hem de teknik nitelikte olabilecek çok sayıda engelli içinde barındırabilir. Zuiderwijk vd. (2012, s.156) açık veri kullanıcısının bakış açısından engellere ilişkin bir genel bakış mevcut olmadığını fakat pek çok kuruluşun bu noktada verilerini yayınlamaya başladığını ifade etmiştir. Elde edilen bulgular bu yönde 


\section{Damar, M. \& Karaman, D.}

değerlendirildiğinde, verinin niteliği, ortaya konulan açık veri web sitesi, verinin künye bilgisi olarak ifade edebileceğimiz tanımlayıcı bilgilerinin gayet nitelikli olduğu görülmektedir.

Bulguları, gerçekleştirilen literatür taraması 1şı̆̆ında değerlendirdiğimizde ise ilgili konuda pek çok hukuki boşluğun bulunduğunu görebiliriz. Türkiye'de Kişisel Verilerin Korunması Kanunu (KVKK, 2016) ve 2019/12 Sayılı Cumhurbaşkanlığg Bilgi ve İletişim Güvenliği Tedbirleri Genelgesi (CBDDO, 2019) kapsamında konu değerlendirildiğinde açık verinin sunulması ve yayılması için pek çok kurala tabi olduğu görülebilir. Fakat açık verinin, kamu kurumlarının şeffaflığı, halka hesap verebilirlik ilkeleri ile örtüşen, önemli bir yanı olduğu ve bu yönde bilişim hukuku, kişisel verilerin korunması, kamu ve devletin önemli bilgilerinin paylaşılması ve doğacak zararlar gibi konularda da farkındalık oluşturulması gerektiği, bu konuda yeterli tartışmanın literatürde yapılmadığı görülebilmektedir.

Toplam davanın \%72,16'sında davalı bununla birlikte \%10.84'ü borçlu taraf olarak bulunmakta toplamda yaklaşık \%83 davalı durumdadır. Elde edilen dava verileri, dava kategorileri konusunda değerlendirildiğinde ise, idare mahkemesi konulu 29.541, hukuk 20.146, icra konulu 9.285, ceza konulu 4.139, vergi 1.039 konulu, icra ve hukuk konulu 72 , cezaya düşen icra konulu 62, savcılık ile ilişkili 2 davaya ulaşılmıştır. Davaların son durumları değerlendirildiğinde sonuçlanmış ve arşive kaldırılan davaların \%42,51'lik bir bölümü oluşturmaktadır (Şekil 2).

Dava konuları değerlendirildiğinde, imar planının iptali davaları 10.674 adet gibi yüksek bir rakam sahiptir. Tüm davalar içinde açık ara birinci sırada yer alan dava konusudur. Kamulaştırmasız el atma konusunda davaların da en yoğun görülen (5.727) ikinci dava olması bir diğer düşündürücü noktadır. Karaca (2018, s.274) kamulaştırmayı, dayanağını anayasadan alan idarenin taşınmaz mal edinme usulü şeklinde tanımlamış fakat kamulaştırma idarenin keyfi bir uygulaması olmayıp bir idari işlem olması sebebiyle nihai amacı kamu yararı taşıması gerektiğini ifade etmiştir. Hukuksal bir dava, davacı tarafından uğranılan haksızlığın giderilmesi amacıyla açılmaktadır. Kurumu davalara taraf yapan ve en fazla mahkemeye çıkaran dava konuları ağırlıkla imar konulu davalar olduğu görülebilir. Kurumda imar konulu davaların kök neden analizi ile sistemli bir şekilde, konunun paydaşlarını içine alarak irdelenmesinde, çözüm aranmasında fayda görülmekedir. Sorunların kaynağına inen, çözüm sunan faaliyetler, gelecekteki dava sayılarını azaltabileceği gibi belediyenin imar hizmetlerinden memnuniyeti artıracağı düşünülmektedir. 


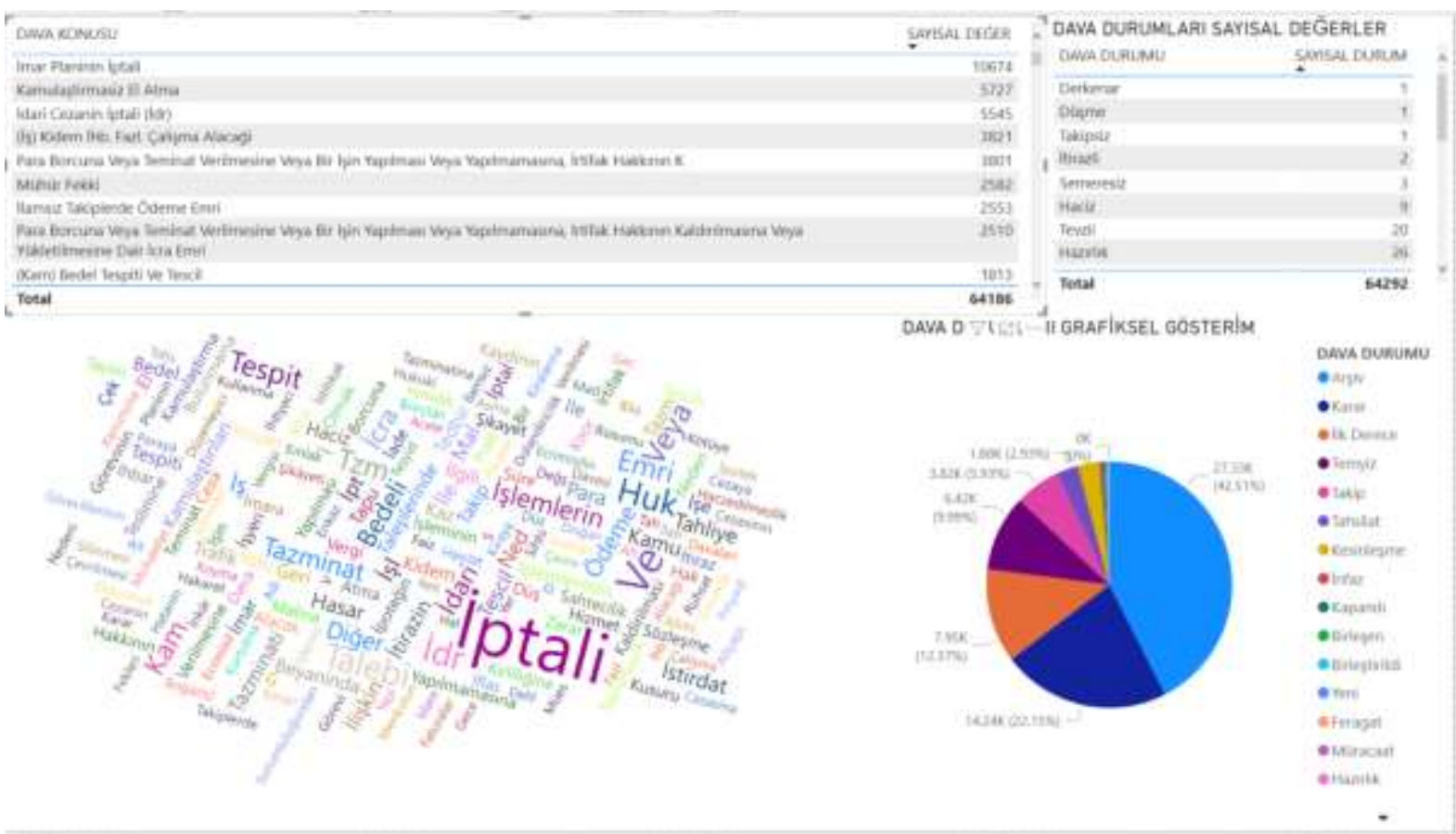

Şekil 2. Dava konusu, durumu filtresi ile dava konularının kelime bulutu ile gösterimi

Davaların tarafları değerlendirildiğinde İBB 46.394 davalı, 6.968 davada borçlu, 5.875 davada davacı, 2.253 davada alacaklı, 1.471 davada yakınan, 651 davada müşteki, 313 davada müdahil, 145 davada tespit istenen, 44 davada katılan davalı, 33 davada katılan davac1, 26 davada tespit isteyen, 6 davada ihbar edilen davalı, 4 davada sanık, 2 davada 3. şahıs, 2 davada davalı-karşı davacı, 1 davada davacı-karşı davalı, şeklindedir (Şekil 3).
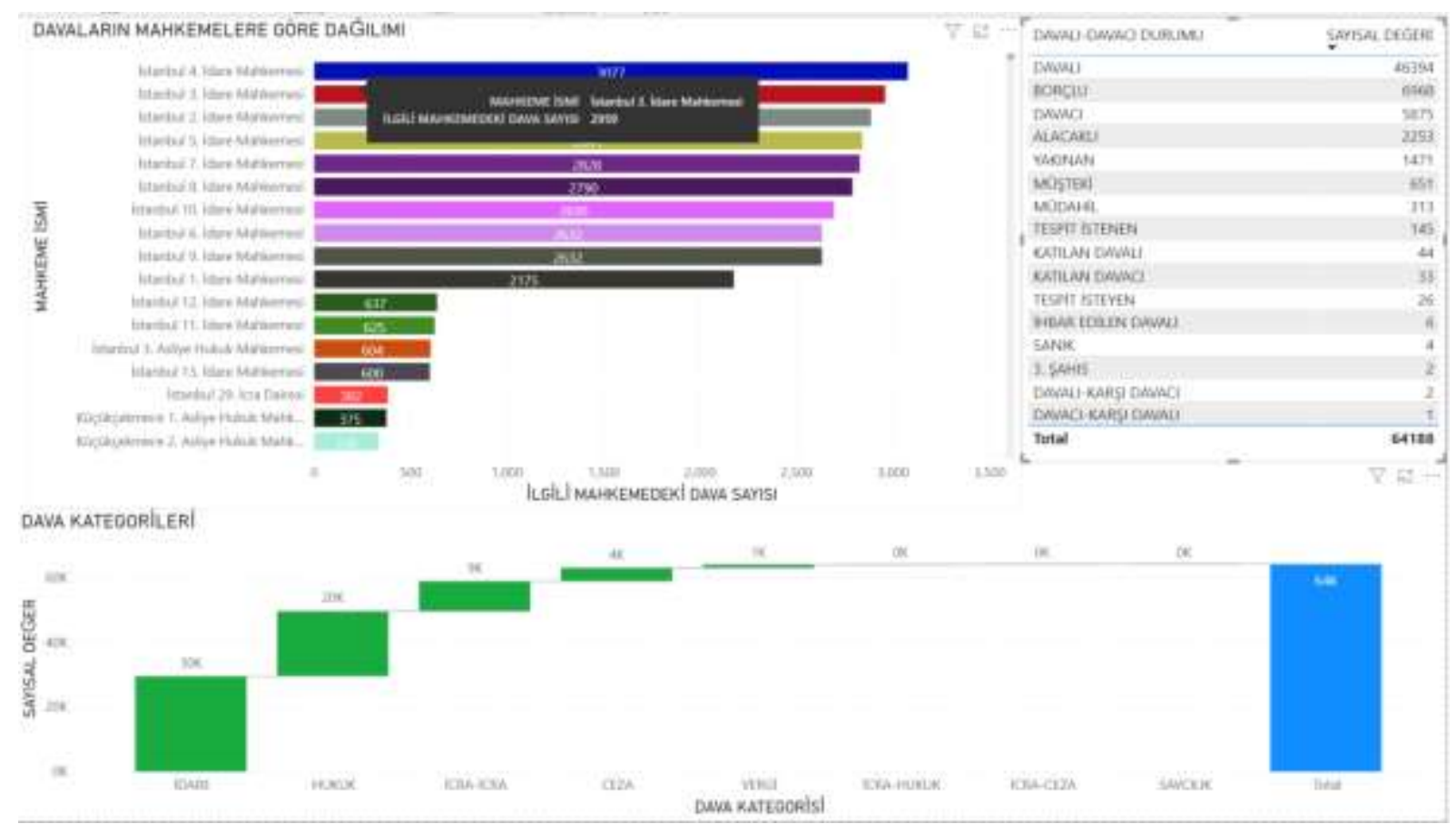

Şekil 3. Davaların mahkemelere ve davaların tür ve durumuna göre gösterimi 


\section{Damar, M. \& Karaman, D.}

Y1lmaz (2020, s.155), ülkemizde, kamulaştırma tüzesi içerisinde hem idarelerin hem de taşınmaz sahiplerinin en büyük sorunlarından birinin, kamulaştırmasız el atma kavramı olduğunu belirtmiştir. Kamulaştırmasız el atma konusunda davaların da en yoğun görülen (5.727) ikinci dava olması da bu bulgu ile örtüşmektedir. Karaca (2018, s.274) kamulaştırmayı, dayanağını anayasadan alan idarenin taşınmaz mal edinme usulü şeklinde tanımlamış fakat kamulaştırma idarenin keyfi bir uygulaması olmayıp bir idari işlem olması sebebiyle nihai amacı kamu yararı taşıması gerektiğini ifade etmiştir.

İdari davalar devlet kurumları tarafından yapılan işe dönük davalardır (Gölcüklü, 1963). Şekil 3'de görülen davaların yoğun görüldüğü mahkemenin idare mahkemeleri olmas1, davalının niteliği ile örtüştüğü ifade edilebilir. Doğal olarak en yoğun açılan ilk beş dava yeri İstanbul (63.843), ardından Ankara (244), İzmir (96), Kocaeli (35), Diyarbakır (24) şeklindedir (Şekil 4).

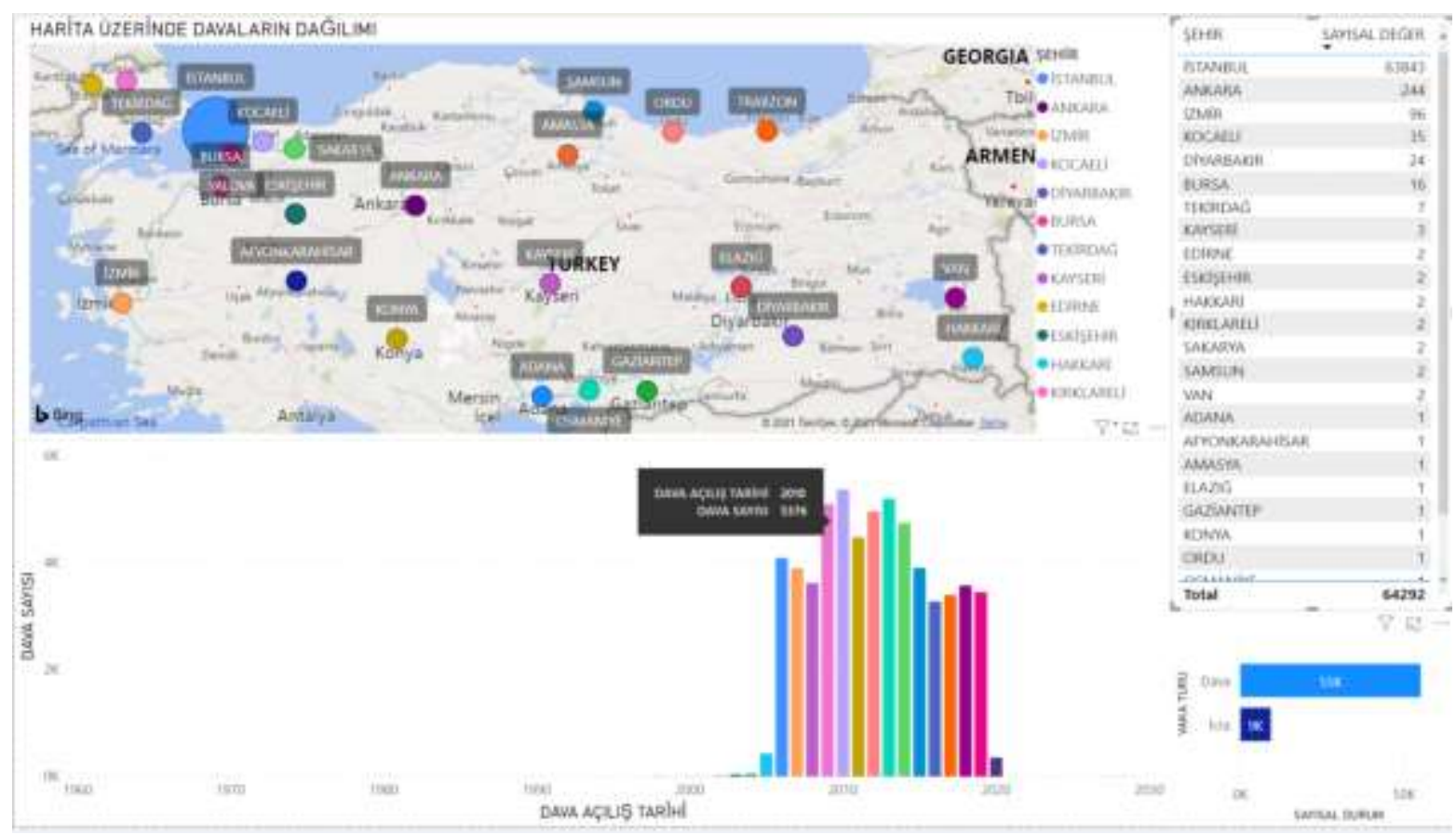

Şekil 4. Dava dosyalarının yıl filtresi ile şehirlere göre dağılımı

Y1llara göre dava verileri; 2020 yılı 355, 2019 yılı 3.453, 2018 yılı 3.575, 2017 y1lı 3.398, 2016 y1l1 3.278, 2015 y1l1 3908, 2014 y1l1 4745, 2013 y1l1 5204, 2012 y11 4965, 2011 y1l1 4479, 2010 y1l 5376, 2009 y1l1 51, 2008 y1lı 3625, 2007 y1l 3903, 2006 y1l1 4092, 2005 y1l1 431, 2004 yıl1 51, 2003 y1l1 42, 2002 y1l1 13, 2001 yıl1 7, 2000 yıl1 5, 1999 y1l1 2, 1998 y1l1 5, 1997 y1lı 2, 1995 yılı 2, 1967 yılı 1, şeklindedir. Yıllar arasındaki görünüm Şekil 4 üzerinde görülebilmektedir. Verilerin dağılımı değerlendirildiğinde yıllar içinde (özellikle bazı dönemler için) değişimin yüksek olduğu bu durumun kayıt altına alınan dava verileri ve arşivleme 
konusunda da araştırmacılar için tartışma oluşturduğu ifade edilebilir. Açık veri paylaşan kurumların araştırmacılara karşı sorumlulukları olduğu, şeffaflık ilkesine bağlı kalarak sunulan bilginin niteliği ve doğruluğu konusunda daha özenli çalışması gereğini ortaya koymaktadır.

Dava dosya konuları bakımından bulgular değerlendirildiğinde, en yoğun açılan üç dava konusu imar planı iptali 10.671, idari cezanın iptali 5.513, personel işleri hakkında davalar 1.628'dir (Şekil 5). İmar planı iptali yukarıdaki diğer grafikle gösterilen bulgular ile örtüşmektedir. İdari cezanın iptali davaları kurumun idari ceza kesme yetkisine sahip bir kurum olmasının getirdiği doğal bir sonuç olarak ifade edilebilir. Fakat personel işleri hakkında açılan davaların yoğun açılan davalar arasında olması bir başka düşündürücü bulgudur.

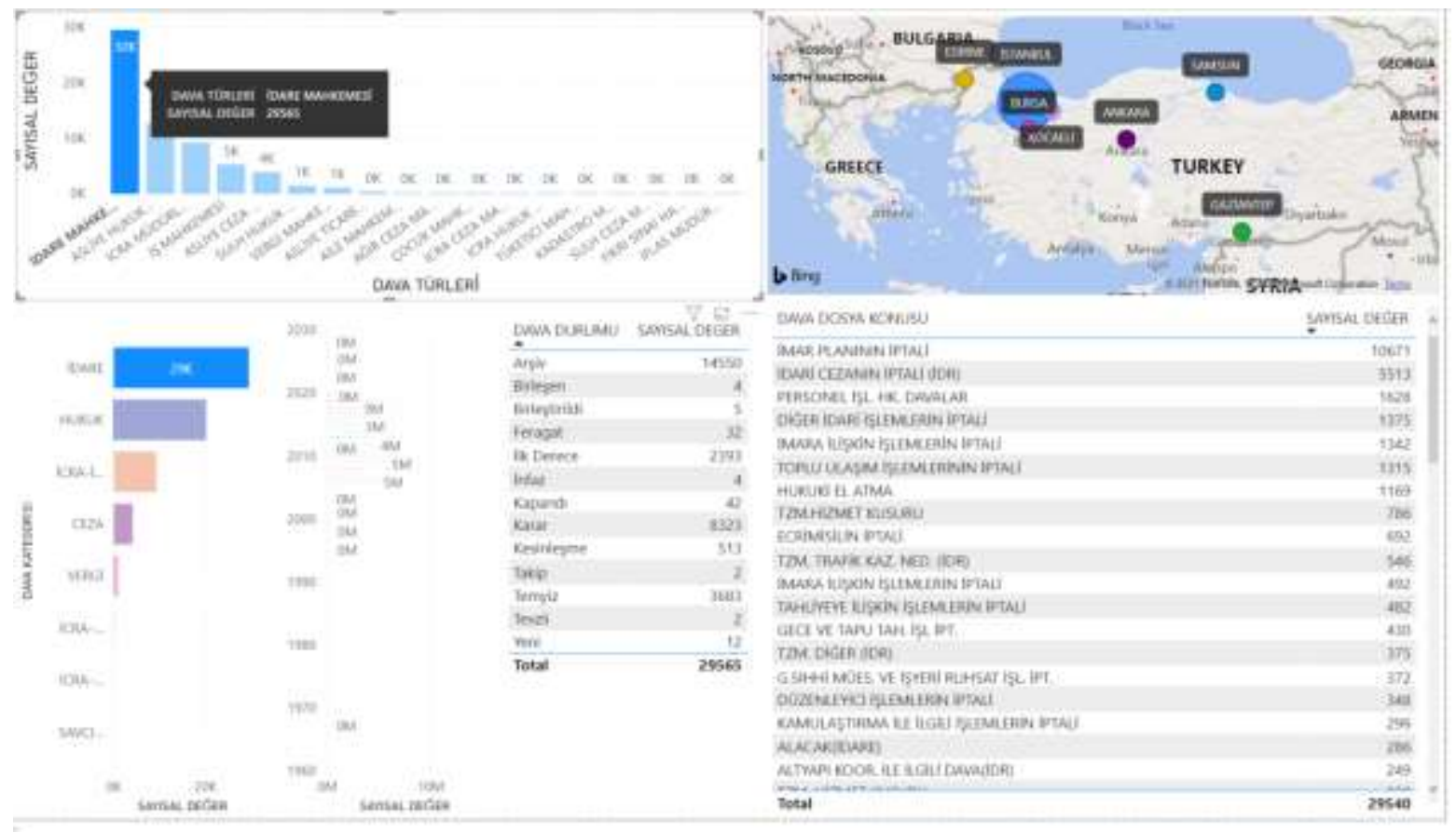

Şekil 5. Dava konu dosyalarının yıl, şehir, dava durumu ve kategorisi açısından görünümü

Bir diğer konuda imar planı davaları ilişkili olduğu düşünülen hukuki el atma davalarının yoğun görülen (1.169) davalar arasında yer almasıdır. Hukuki el atma; "uygulama imar planlarında umumi hizmetlere ve resmî kurumlara ayrılmak suretiyle, mülkiyet hakkının özüne dokunacak şekilde, bir taşınmaza ilişkin tasarrufun hukuken kısıtlanması" şeklinde ifade edilmektedir. Yılmaz (2020) bu kavramın, 1950'lerden günümüze kadar farklı kanun düzenlemeleri ve yargı kararları ile şekillenen ve gelişen bir tüzel süreç yaşadığını ifade etmiştir. Anayasa'nın 35'inci maddesi ile güvence altına alınmış olan mülkiyet hakkı ancak kamu yararının gerektirdiği durumlarda sınırlandırılabilmektedir (Çağdaş, 2001). Hukuki el atmaların ve imar planı iptali gibi davaların yoğun olması Türkiye' deki tüm belediyelerde ortak görülen, Türkiye'nin kentleşme sürecinde yaşadığı bir diğer sorun olarak karşımıza 


\section{Damar, M. \& Karaman, D.}

çıkmaktadır. Bu dava verileri de bu durumu ispat eden, Türkiye'nin şehirlerinin iyi düşünülmüş, şehir planlarına, bölgesel gelişme planlarına, imar planlarına ihtiyacı olduğunun bir bulgusu olarak değerlendirilebilir. Bu durumun davalara konu olması da vatandaş ve kurumlar arasında bir tartışmalı konu olduğu, problemin temel paydaşı olan vatandaşın, durumu vatandaşın mutluluğu, toplum faydası ve toplumun huzuru için yönetmesi gereken belediyenin ise bu konuda yoğun sorun yaşadığını göstermektedir. $\mathrm{Bu}$ durum literatür çerçevesinde değerlendirildiğinde, tarihsel süreç içinde pek çok belediyemizde ortak görülen, diğer belediyeler ile benzerlik taşıyan, literatürde değerlendirmelerde bulunulmuş bir konu olarak karşımıza çıkmaktadır (Baba, 2016; Çolak \& Öngören, 2011; Eminagaoglu, 2018; Köktürk, 2019). Fakat hukuki hak arayışı içinde imar planları, kamulaştırma, hukuki el atma gibi konuların yoğun olması sadece İBB tarafından değil, tüm belediyeler ve kamu imar planları tarafları tarafından da ayrıca sorgulanması gerektiği ifade edilebilir.

\section{SONUÇ VE ÖNERILER}

Tüm bu elde edilen bulgular, gerçekleştirilen veri analizi ve geliştirilen uygulama gerek açık veri ve açık bilim konularına farklı iş zekası uygulaması ile farklı ve güncel bir bakış açısı ortaya koymuş, Türkiye'de ve dünyada bu konuda gerçekleşen çalışmaları kapsamlı literatür araştırması ile değerlendirerek, Türkçe literatüre öncü bir katkı ortaya konulmuştur.

Ele alınan tüm kavramsal çerçeve ve özellikle açık bilim, açık veri ve açık hükümet verileri tanımları dahlinde Türkiye'deki açık veri kavramının hukuksal olarak da özellikle tartışılması gerektiği izlenimini ortaya koymuştur. Açık veri paylaşımı, kullanımı, kurumların niteliği gibi pek çok konular bağlamında ortaya çıkacak hukuksal tartışmaların gerek Türkçe literatür gerekse dünyadaki örnek çalışmalar değerlendirildiğinde biraz gerisinde bulunduğumuz ifade edilebilir. Bu alanda daha fazla çalışma ve araştırmanın gerçekleştirilmesi gerektiği, konunun tüm kamu kurumlarını bağlayacak şekilde kapsamlı, tüm kanunlar ile ilişkili, çatı bir yapıya kavuşturulması gerektiği ifade edilebilir. Bu sayede açık verinin kullanımından doğabilecek sakıncalar hususunda veri sahibi kurum ve kuruluşların zarar görmesi engellenecek, hem de bu veriden faydalanacak araştırmacıların korunması, araştırma bulgularının ilgili kurumların etkinliğini artırması, alana katkı sunması sağlanabilecektir.

Türkiye'de açık veri kaynakları ve sunulan verinin şeffaflık ilkesi yanında ortaya konulacak araştırma bulguları ve analizlerin potansiyel katkısı değerlendirildiğinde, açık veri ve özellikle açık hükümet verileri konusunda daha fazla çalışma yapılması gerektiği 
görülmektedir. TÜBİTAK, bazı belediyeler, bazı kamu kurumlarının bu konuda web siteleri aracılığı çalışmalar yürüttüğü görülebilmektedir. Fakat araştırmamız sonucunda elde ettiğimiz bulgular 1şığında konu değerlendirildiğinde bu sayı yeterli olmamak ile birlikte, verinin kısıtlı olduğu, özellikle kamu kurumlarının, belediyelerin, harcama bilgileri konusunda yeterli veri sunmadığı görülmüştür. Örneğin dava harcamalarını, oluşan tazminat giderler, dava masrafları, olayın yarattığı kamu zararı ve kurum zararı, kuruma mali girdi ve çıktısı gibi diğer verilerin de bu açık veri içinde bulunması, araştırmacılara ve alan ile ilgili taraflara daha nitelikli ve kapsamlı analiz imkânı sağlayacaktır. Bunun yanında kamunun daha şeffaf bilgilenmesi için de kaynak oluşturacağı ifade edilebilir. Mevcut haliyle açık verinin, siyasi bir hak olan bilgi özgürlüğü için gerekli olan tepkisel bir amaç gütmeyen, toplumsal katkı ve bilimsel değeri ön plana alan hedef odaklı bir politika olduğu unutulmaması gerekmektedir.

Ortaya konulan iş zekâsı kavramsal çerçevesi içinde veri ve bu verinin niteliği temel kaynak ve olmazsa olmazdır. Dolayısı ile açık veri iş zekâsı teknolojisi için önemli bir kaynak niteliği taşımaktadır. Bu iki kavram ve teknoloji birbiriyle organik bir bağa sahiptir. Özellikle iki kavram içinde gerçekleştirilen literatür değerlendirilmesinde gerçekleştirilen çalışma iş zekası konusunda da literatüre farklı bir yöntemsel kazanım ve veri kaynağı için sadece belli kaynaklara değil, açık ve herkes tarafından kullanılabilen kaynaklara yoğunlaşabilmesi için farkındalık oluşturduğu ifade edilebilir.

Topuzkanamış (2013), modern toplumlar için hukuk kavramı, rasyonel bir düzen tasavvuru olarak değerlendirmektedir. Modern toplum, kapitalist üretim ilişkileri, endüstriyel gelişme, gözetim ve merkezileşmiş siyasi iktidar gibi temel unsurları içinde barındırdığını ve çok yönlü bir problem olan hukuka uyma, salt hukuk düzeninin pozitif hukuktaki imgesini incelemek yoluyla anlaşılamayacağını ifade etmiştir. Gerçekleştirilen bu uygulamanın bir yönüyle Türkiye'nin en büyük şehrindeki hukuksal problemlerin değerlendirilmesi ve durumunu ortaya koyması adına değer taşımaktadır. Sonuçta mahkemeler ve mahkemelerde çözüm bulması amacıyla açılan davalar, tarafların çıkarlarının çatışması sonucu açılmakta ve hakların yasa ve kurallar çerçevesinde aramaları içindir. Bu nedenle, gerek şeffaflık ilkesi gereği, gerekse veri sahibi kurumun Türkiye'nin en büyük ve kalabalık şehri olması niteliği ile de bulgular önem taşımakta, İBB'nin anlaşmazlığa düştüğü mahkeme konuları hususunda genel bir doku ve eğilimi de ortaya koymaktadır.

Çalışma için hem bir kısıt hem de bir bulgu olarak, sunulan açık verinin daha özenli ve daha nitelikli veriyi içinde barındırmasının veri analizinden daha değerli bulguların çıkma 
imkânını artıracağı ifade edilebilir. Ayrıca çalışmada iş zekâsı teknolojisi, kavramsal olarak ortaya konulmuş ve güncel bir konu olan açık veri ortamları üzerinden İBB Dava Bilgileri kapsamı ile veri ve hukuk alanındaki uzmanlarca kapsamlı bir değerlendirme ortaya konulmuştur. Veri setinin elde edilmesi, düzenlenmesi ve iş zekâsı teknikleriyle görselleştirilmesi ve analiz edilmesi sayesinde detaylı bir şekilde ortaya konulmaktadır. Dava verilerinin illere göre yoğunluğu, hangi tür davalarda yoğunlaşmanın yaşandığı, dava konuları içinde metin analizi, yıllara göre bu davaların dağılımı gibi pek çok yönden konu değerlendirilmiştir. $\mathrm{Bu}$ sayede sunulan açık veriden araştırmacılar neler elde edebilir, bu verideki eksiklikler nelerdir, daha nitelikli açık veri paylaşımı nasıl yapabilir ve araştırmacılara, paylaşan kuruma neler kazandırabilir bütüncül bir bakış açısı sunulmuştur.

\section{TEŞEKKÜRLER}

Açık veri kaynanı araştırmacılara açan İstanbul Büyükşehir Belediyesi’ne, veri portalının ortaya çıkmasını sağlayan çalışanlarına, ayrıca açık bilim ve açık veri konusundaki önemli ve değerli çalışmaları için TUBİTAK'a ve değerli çalışanlarına teşekkürlerimizi sunariz.

\section{REFERENCES / KAYNAKLAR}

Abukari, K., \& Job, V. (2003). Business intelligence in action. CMA Magazine, 77(1), 15-30.

Açık Bilim Türkiye. (2021). Açık bilim Türkiye. Erişim tarihi: 17.03.2021, https://acikbilim.org/

Ateş, H. (2008). Karar vermede iş zekâsının önemi: Tekstil sektöründe bir araştırma (Basılmamış yüksek lisans tezi). Dokuz Eylül Üniversitesi, İzmir.

Baba, G. İ. (2016). Belediyelerin imar konusunda yetki ve görevleri. İstanbul Aydın Üniversitesi Hukuk Fakültesi Dergisi, 2(1), 173-194.

Bizer, C., Heath, T., \& Berners-Lee, T. (2009). Linked data - the story so far. International Journal on Semantic Web and Information Systems, 5(3), 1-22. doi:10.4018/jswis.2009081901.

Blockchain Türkiye. (2021). Blockchain Türkiye açık veri. Erişim tarihi: 17.03.2021, https://bctr.org/dokumanlar/Acik_Veri.pdf

Carolan, L., Smith, F., Protonotarios, V., Schaap, B., Broad, E., Hardinges, J., \& Gerry, W. (2015). How can we improve agriculture, food and nutrition with open data. United Kingdom: Open Data Institute.

CBDDO. (2019). Cumhurbaşkanlı̆̆ dijital dönüşüm ofisi. 2019/12 Sayılı Cumhurbaşkanlığı Bilgi ve İletişsim Güvenliği Tedbirleri Genelgesi. Erişim tarihi: 15/03/2021, https://cbddo.gov.tr/mevzuat/2019-12-sayili-bilgiguvenligi-tedbirleri-cumhurbaskanligi-genelgesi/ 
Çağdaş, V. (2001). 2942 Sayılı Kamulaştırma Yasası'nda yapılan değişikliklere taşınmaz değerlemesi açısından bakış. Mülkiyet, 42, 16-19.

Çolak, N. İ., \& Öngören, G. (2011). Imar planlarl, imar uygulamalart ve iptal davalart. Erişim tarihi: 23.03.2021, http://www.ilkercolak.com.tr/wpcontent/uploads/2015/06/imar_planlari_imar_uygulamalari_ve_iptal_davalari.pdf

Eckerson, W. (2003). Smart companies in the 21st century: The Secrets of creating successful business intelligent solutions. tdwi report series, the data warehousing institute. Erişim tarihi: 13.04.2021, http://download.101com.com/tdwi/research_report/2003BIReport_v7.pdf

Elena, C. (2011). Business intelligence. Journal of Knowledge Management, Economics and Information Technology, 1(2), 1-12.

Eminagaoglu, Z. (2018). Examination of zoning plan modifications and effects on whole plan: Artvin sample. International Journal of Scientific and Technological Research, 4(9), 69-80.

EuropaData. (2021). European open data portal. Erişim tarihi: 24.03.2021, https://data.europa.eu/euodp/en/data/

European Data Portal. (2021). Avrupa Birliği veri portall. Erişim tarihi: 16.03.2021, https://www.europeandataportal.eu/en

Fecher, B., \& Friesike, S. (2014). Opening science. In S. Bartling \& S. Friesike (Eds.), One term, five schools of thought (pp.17-47). Cham: Springer.

Foley, É., \& Guillemette, M. G. (2010). What is business intelligence? International Journal of Business Intelligence Research (IJBIR), 1(4), 1-28.

Golub, K., \& Lund, A. (2021). Why open government data? The case of a Swedish municipality. Journal of Data and Information Science, 6(1), 120-138.

Gölcüklü, F. (1963). “İdari Ceza Hukuku” ve anlamı; idarenin cezai müeyyide tatbiki. Ankara Üniversitesi Siyasal Bilgiler Fakültesi Dergisi, 18(02), 115-182.

Halonen, A. (2017). Being open about data. Erişim tarihi: 16.03.2021, http://www.fininst.uk/wpcontent/uploads/2017/09/being-open-about-data.pdf

Hartley, K., \& Seymour, L. F.(2010). Towards a framework for the adoption of business intelligence in public sector organisations: The case of South Africa. Proceedings of the South African Institute for Computer Scientists and Information Technologists Conference (SAICSIT 11), October 3-5, 2010, Cape Town, South Africa.

Heinrichs, J. H., \& Lim, J. S. (2003). Integrating web-based data mining tools with business models for knowledge management. Decision Support Systems, 35(1), 103-112.

İBB Açık Veri. (2021). IBBB açık veri portalı Istanbul Büyükşehir Belediyesi. Erişim tarihi: 17.03.2021, https://data.ibb.gov.tr/

İzmir Açık Veri. (2021). İzmir Büyükşehir Belediyesi açık veri portalı. Erişim tarihi: 17.03.2021, https://acikveri.bizizmir.com/

Karaca, E. (2018). Kamulaştırmasız el koymanın unsurları ve kamulaştırmasız el koymaya karşı yargısal başvuru yollar1. Türkiye Barolar Birliği Dergisi, 137, 273-309.

Kazaz, P. (2020). Türkiye açık veri girişimi için konumsal veri perspektifinden öneriler geliştirilmesi (Basılmamış yüksek lisans tezi). Karadeniz Teknik Üniversitesi, Trabzon.

Kostovski, M., Jovanovik, M., \& Trajanov, D. (2012). Open data portal based on semantic web technologies. Proceedings of the 7th South East European Doctoral Student Conference (pp.1-13), 24-25 September 2012, Thessaloniki, Greece. 


\section{Damar, M. \& Karaman, D.}

Köktürk, E. (2019). Türkiye'de imar sorunları ve kent, inşaat ve ekonomiye etkileri. Kent, Inşaat ve Ekonomi Kongresi (ss. 240-306), 2-4 Mayıs 2019, Gaziantep, Turkey.

KVKK. (2016). Kişisel Verilerin Korunması Kanunu. Kanun No: 6698. Erişim tarihi: 17.03.2021, https://www.mevzuat.gov.tr/mevzuat?MevzuatNo=6698\&MevzuatTur=1\&MevzuatTertip=5

Marković, M., Gostojić, S., Sladić, G., Stojkov, M., \& Milosavljević, B. (2016). Survey of open data in judicial systems. In 6th International Conference on Information Society, Technology and Management (pp. 64-69). Beograd, Serbia, Informaciono društvo Srbije.

Mitchell, R., \& Boyle, B. (2010). Knowledge creation measurement methods. Journal of Knowledge Management, $14(1), 67-82$.

Mudzana, T., \& Maharaj, M. (2015). Measuring the success of business-1ntelligence systems in South Africa: An empirical investigation applying the delone and mclean model. South African Journal of Information Management, 17(1), 1-7.

ObamaWhiteHouse. (2021). The white house presidentBarack Obama. Erişim tarihi: 24.03.2021, https://obamawhitehouse.archives.gov/open

Open Definition. (2021). Open knowledge foundation. defining open in open data, open content and open knowledge. Erişim tarihi: 16.03.2021, http://opendefinition.org/

Opengovdata. (2021). The annotated 8 principles of open government data. Erişim tarihi: 16.03.2021, https://opengovdata.org/

Pham, Q. T., Mai, T. K., Misra, S., Crawford, B., \& Soto, R. (2016). Critical success factors for implementing business intelligence system: Empirical study in Vietnam. International Conference on Computational Science and Its Applications (pp. 567-584). İsviçre, Springer, Cham.

Pollock, R. (2011). Open data: A means to an end, not an end in itself, open knowledge foundation blog. Erişim tarihi: 16.03.2021, https://blog.okfn.org/2011/09/15/open-data-a-means-to-an-end-not-an-end-in-itself/

Rouder, J. N. (2016). The what, why, and how of born-open data. Behavior Research Methods, 48(3), 1062-1069.

Seddon, P. B. (1997). A respecification and extension of the DeLone and McLean model of IS success. Information Systems Research, 8(3), 240-253.

Sharda R., Delen, D., \& Turban, E. (2015). Business intelligence and analytics: Systems for decision support. United Kingdom: Pearson.

Sowe, S. K., \& Zettsu, K. (2015). Towards an open data development model for linking heterogeneous data sources. 2015 Seventh International Conference on Knowledge and Systems Engineering (KSE 2015) (pp. 344347), 8-10 October 2015, Vietnam.

Topuzkanamıș, E. (2013). Hukuk ve disiplin: Modern toplumda hukuka uymanın dayanakları (Basılmamıș doktora tezi). Dokuz Eylül Üniversitesi, İzmir.

TÜBİTAK Açık Bilim. (2021). TÜBİTAK açık bilim politikası. Erişim tarihi: 17.03.2021, https://acikveri.ulakbim.gov.tr/wp-content/uploads/2019/03/TÜBİTAK-Aç1k-Bilim-Politikası.pdf

Welle Donker, F., \& van Loenen, B. (2017). How to assess the success of the open data ecosystem? International Journal of Digital Earth, 10(3), 284-306.

Wowczko, I. A. (2013). The use of BI in government driven environment. Business Intelligence and Data Mining, 29(1), 1107-1111.

Yılmaz, A. (2020). Kamulaştırmasız el atma ve hukuki el atma kavramlarının tüzel gelişiminin incelenmesi. Jeodezi ve Jeoinformasyon Dergisi, 7(2), 155-183. 
Zuiderwijk, A., Janssen, M., Choenni, S., Meijer, R., \& Alibaks, R. S. (2012). Socio-technical impediments of open data. Electronic Journal of e-Government, 10(2), 156-172. 